\title{
Influence of river-ocean plumes upon bacterioplankton production of the Strait of Georgia, British Columbia
}

\author{
L. J. Albright \\ Department of Biological Sciences, Simon Fraser University, Burnaby, B. C., Canada V5A 1S6
}

\begin{abstract}
Stimulation in bacterioplankton glucose heterotrophic activities and productivities occurs when river water (Fraser, Squamish and Homathko-Southgate rivers) enter the saline surface waters of the Strait of Georgia, British Columbia, Canada. As the lower salinity water of the Fraser plume (ca. half of the fresh water flow into this Strait comes from this river) mixes into adjacent surface waters of the Strait, bacterioplankton production remains significant till the salinity exceeds ca. $20 \% \mathrm{~S}$. Since lower salinity water (i.e. $\leq$ ca. $20 \%$ S) from river plumes covers extensive areas of the Strait of Georgia during the annual freshet (ca. April to July) there is a significant annual bacterial contribution to total microbial production within this estuarine ecosystem.
\end{abstract}

\section{INTRODUCTION}

The Strait of Georgia which has a calculated volume of ca. $1025 \mathrm{~km}^{3}$ of estuarine water, annually receives about $145 \mathrm{~km}^{3}$ of runoff water, mainly from rivers, creeks and streams (Waldichuk, 1957). This annual fresh water addition is thus about $14 \%$ of the volume of water contained within this semi-enclosed marine basin. However, because of density characteristics the fresh water tends to remain at the surface where it greatly dilutes the sea water. Fig. 1 illustrates the relative content of fresh and sea waters within the 0 to $10 \mathrm{~m}$ water column of the Northern (area north of the southern tip of Texada Island) and Central (area between Haro Strait and the southern tip of Texada Island) Domains of the Strait of Georgia (Fig. 2). The fresh water content varies from 14 to $39 \%$ with peak values occurring in the Central Domain in mid-summer. The lowest freshwater concentrations occur during winter (December-March).

The fresh waters of the rivers and creeks which flow into this Strait are generally bacterial dominated and many have relatively high silt loads (Seki et al., 1969; Bell and Albright, 1981; Valdes and Albright, 1981). The clearer and more stable euphotic waters of the Straight of Georgia tend to be microalgal dominated ecosystems (Parsons et al., 1980). These 2 water types meet and mix in river-ocean plumes where there is a transfer of significant quantities of microbial biomasses, organic nutrients and silt loads into this strait.

To place this nutrient and microbial transfer by river, creek and stream flow in perspective it is useful to calculate approximate autochthonous and allochthonous organic carbon additions to this strait. Based upon a water surface area of $6420 \mathrm{~km}^{2}$ (Waldichuk, 1957) and an estimate of $285 \mathrm{~g} \mathrm{C} \mathrm{m}^{-2} \mathrm{yr}^{-1}$ (Harrison et al.,

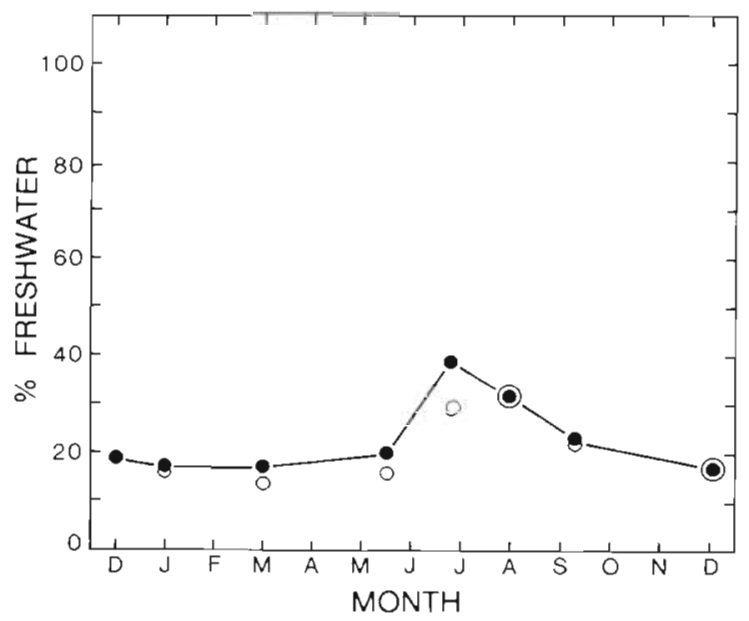

Fig. 1. Percent content of fresh and sea waters within the 0 to $10 \mathrm{~m}$ water columns of Central $(\bullet)$ and Northern $(0)$ Domains of the Strait of Georgia. Replot of data by Waldichuk (1957) 
in press) as the mean primary production, the annual phytoplankton production of this strait is ca. $18.3 \times 10^{11} \mathrm{~g} \mathrm{C} \mathrm{yr}^{-1}$. If the total organic carbon (TOC) content of the lotic systems which enter the strait is taken as $5 \mathrm{mg} \mathrm{l}^{-1}$ and the total runoff value is $145 \mathrm{~km}^{3}$ $\mathrm{yr}^{-1}$ this is a calculated addition of approximately $7.3 \times 10^{11} \mathrm{~g} \mathrm{C} \mathrm{yr}^{-1}$ to the strait, which is approximately $40 \%$ of the phytoplankton primary production. In an earlier study Seki et al. (1969) concluded that the allochthonous organic carbon addition to this strait was approximately equivalent to the autochthonous organic carbon production.

A proportion of the TOC of Fraser river fresh water is bacterial cells which vary in concentrations from ca.
$1.6 \times 10^{6}$ to $2.9 \times 10^{7} \mathrm{ml}^{-1}$ depending upon the flow conditions (Bell and Albright, 1981; Valdes and Albright, 1981). If $1.2 \times 10^{7} \mathrm{ml}^{-1}$ (Bell and Albright, 1981 ) is taken as the mean bacterial content of this and other rivers and streams which enter the strait then this is an annual addition of approximately $1.7 \times 10^{24}$ cells $\mathrm{yr}^{-1}$. If each cell is assumed to have an average carbon content of ca. $8.5 \times 10^{-15} \mathrm{~g}$ (Valdes and Albright, 1981) the added bacterial carbon is ca. $1.5 \times 10^{10} \mathrm{~g} \mathrm{yr}^{-1}$ which is approximately $3.4 \%$ of the river and stream borne TOC.

These calculations indicate that runoff water additions of organic carbon to the Strait of Georgia are significant. Hence the following question becomes

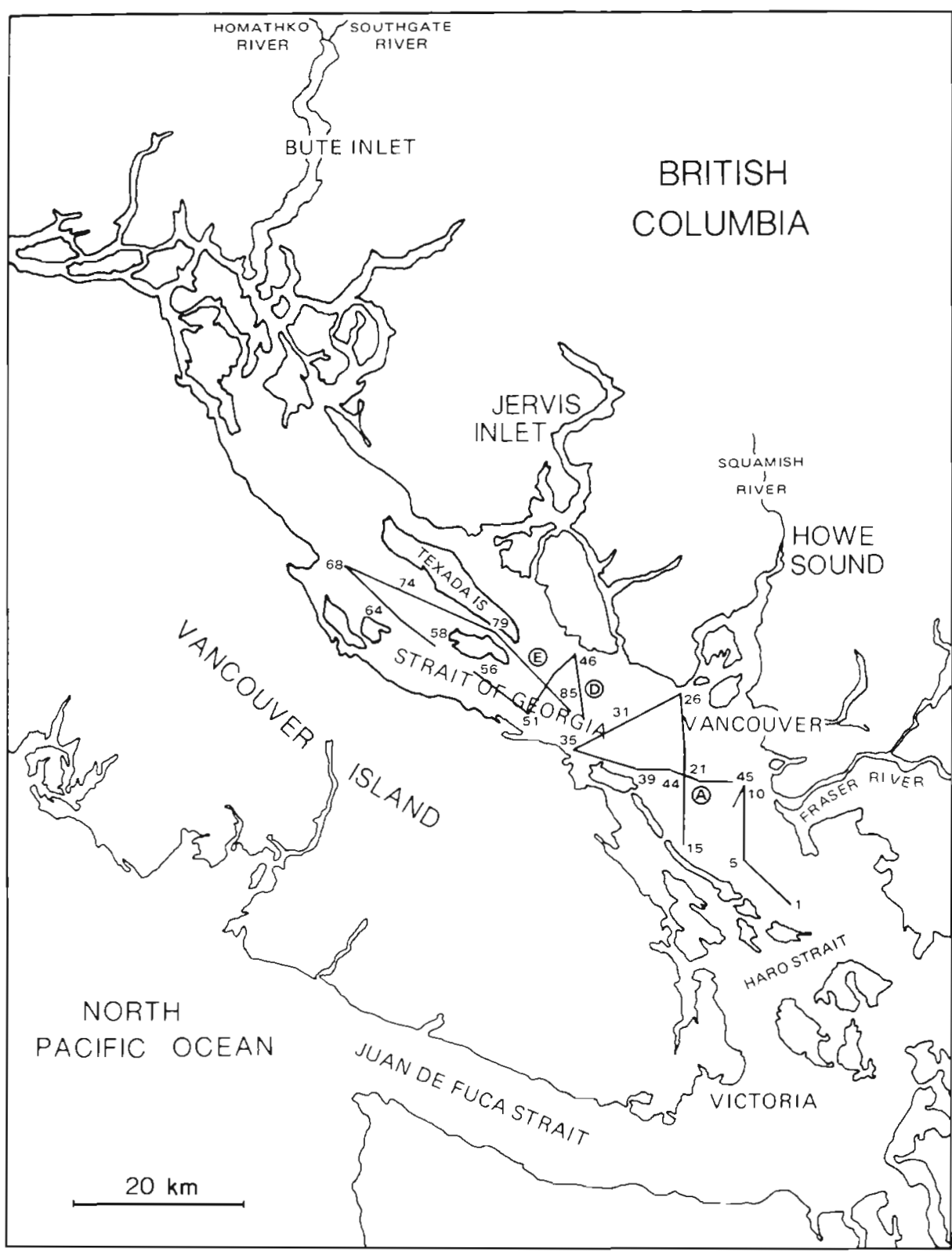

Fig. 2. Strait of Georgia, 29 June to 2 July 1981 sampling track. Numbers: locations of samples analysed for bacterial numbers and productivities, chl. a concentrations and salinities 
Fig. 3. Bacterial numbers, glucose heterotrophic activities and productivities of the Fraser, Squamish and Homathko-Southgate plumes, 2 Feb. 1980, 6 Dec. 1981, 29 Sept. 1980. Bacterial productivities determined by technique of Fuhrman and Azam (1982) (Squamish plume) and Romanenko et al. (1972) (Fraser and Homathko-Southgate plumes)

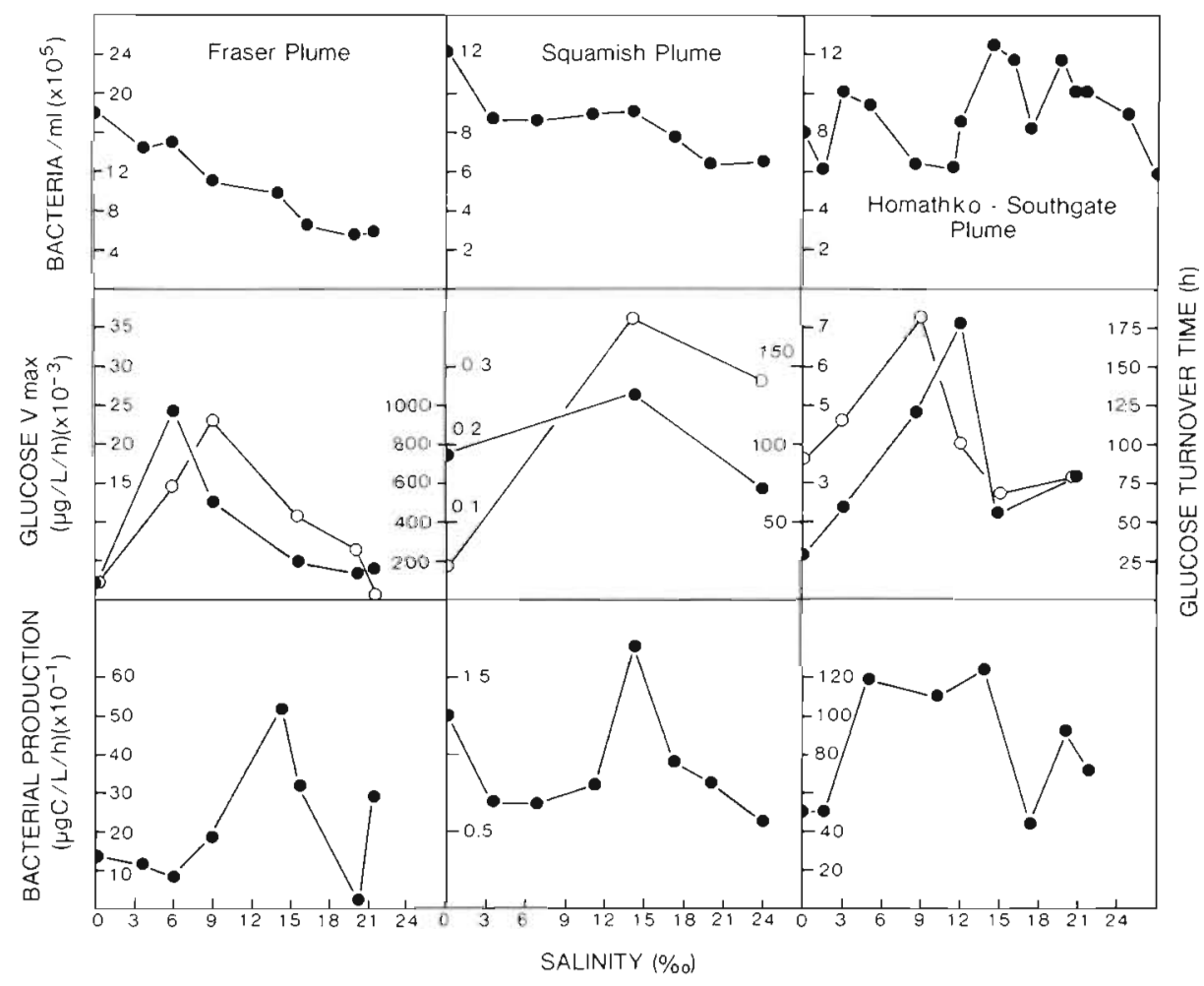

germane. What is the influence of these lotic systems' organic carbon and bacterial additions upon microbial biomasses and productivities in the surface estuarine waters of the Strait of Georgia?

\section{MATERIALS AND METHODS}

Water for the various microbiological analyses was obtained from a depth of $1 \mathrm{~m}$ (surface samples) using a Van Dorn sampler (data of Table 1, Fig. 3) and a depth of ca. $3 \mathrm{~m}$ using the underway sampling system of Mackas et al. (1980) (data of Fig. 4).

Bacterial numbers were assayed using the acridine orange direct count technique of Hobbie et al. (1977) and Daley and Hobbie (1975); these values were used to calculate biomasses as per Valdes and Albright (1981).

Glucose heterotrophic activities were determined using D-6- $\left[{ }^{3} \mathrm{H}\right]$ glucose, specific activity $22.5 \mathrm{Ci} \mathrm{mM}^{-1}$ Amersham, and the technique of Azam and HolmHansen (1973) as modified by Valdes and Albright (1981).

Estimates of heterotrophic bacterial production were done using the dark ${ }^{14} \mathrm{CO}_{2}\left(\mathrm{Na}_{2} \mathrm{CO}_{3}\left[{ }^{14} \mathrm{C}\right]\right.$ - specific

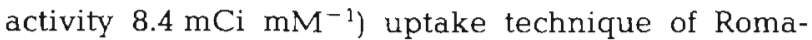
nenko et al. (1972) and the tritiated thymidine (methyl${ }^{3} \mathrm{H}$-thymidine, sp. act. $74.1 \mathrm{Ci} \mathrm{mM}^{-1}$, New England Nuclear) technique of Fuhrman and Azam (1980, 1982). Bacterial production as determined by the assay of Romanenko et al. (1972) is subject to rather large experimental errors (e.g. Overbeck and Daley, 1973) whereas the thymidine incorporation assay of Fuhrman and Azam $(1980,1982)$ is a conservative determination of bacterioplankton production. Hence, the results of the 2 assays are not directly comparable.

Chlorophyll a concentrations were assayed by Dr. D. Mackas as per Mackas et al. (1980).

\section{RESULTS AND DISCUSSION}

Previous investigations have shown that a stimulation of bacterial glucose heterotrophic activities occurs in Fraser plume waters of ca. 5 to $10 \%$ S (Valdes and Albright, 1981; Bell and Albright, 1981) and that bacterial productivities increase to maximum values at ca. 12 to $18 \%$ S (Albright, 1983). This observed stimulation in bacterial production occurs throughout the year and at a given plume salinity, the bacterial productivity appears to remain relatively constant although primary production varies considerably (Albright, 1983).

That the stimulation in bacterial glucose heterotrophic activity is not restricted to the Fraser plume is indicated by Fig. 3. Both the Squamish and HomathkoSouthgate rivers, which are the main lotic systems entering the Strait of Georgia contiguous fiords of Howe Sound and Bute Inlet respectively, also have plumes which display stimulations in bacterial glucose 


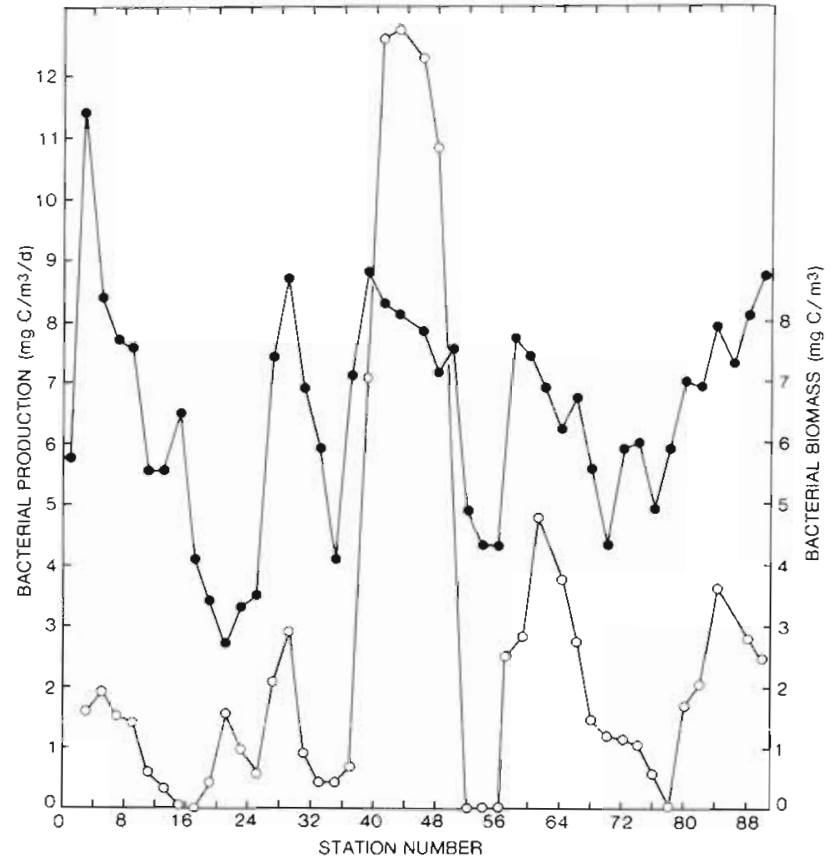

Fig. 4. Transect plots of bacterial biomasses ( $\bullet$ ) and productivities (O) (assayed by technique of Fuhrman and Azam, 1982) for sampling locations of Fig. 2

heterotrophic activities and productivities. Based upon these data it is possible that the other rivers and streams which enter this strait also have plumes with increased bacterial acitivities and productivities.

If one considers the flow regimes of the rivers and streams that enter the Strait of Georgia, the smaller ones probably have limited impact beyond their immediate plumes. However, the much larger Fraser plume should significantly influence the bacterial ecology of the surrounding Strait waters. To test this hypothesis a transect to sample surface waters of the Central and a portion of the Northern Domains of the Strait of Georgia was done on 29 June to 2 July 1981 (see Fig. 2 for the cruise track). The bacterial cells in these surface waters have dimensions of approximately $0.48 \mu \mathrm{m}$ width $\times 0.48 \mu \mathrm{m}$ length and hence a mean volume of ca. $0.058 \mu \mathrm{m}^{3}$. These cells are therefore somewhat smaller than the bacteria found within the Fraser river freshwater and its immediate plume (Valdes and Albright, 1981). Based upon a cell density of $1.07 \mathrm{~g} \mathrm{~cm}^{-3}$ (Lamanna et al., 1973), a carbon-to-dryweight ratio of 0.50 (Luria, 1960) and a dry-to-wetweight ratio of 0.22 (Luria, 1960; Lamanna and Mallette, 1965), the mean cell mass was calculated as $6.8 \times 10^{-15} \mathrm{~g} \mathrm{C}$. Mean bacterial biomass and number of this strait's surface waters were therefore $6.6 \mathrm{mg} \mathrm{C}$ $\mathrm{m}^{-3}$ and $9.6 \times 10^{11} \mathrm{~m}^{-3}$ respectively; the mean bacterial productivity was assayed as $1.51 \mathrm{mg} \mathrm{C} \mathrm{m}^{-3} \mathrm{~d}^{-1}$ $\left(2.2 \times 10^{11}\right.$ cells $\left.\mathrm{m}^{-3}\right)$ (when assayed by the technique of Fuhrman and Azam, 1982) (Fig. 4). There were no significant differences between bacterial numbers and productivities of surface waters of the 2 domains.

A comparison of the bacterial productivity and salinity data of Figs. 4 and 5 indicates that where the surface salinities decrease to approximately $20 \%$ or less, bacterial productivities significantly increase (except in one area - see below). These lower salinity water masses which contain the more productive bac-

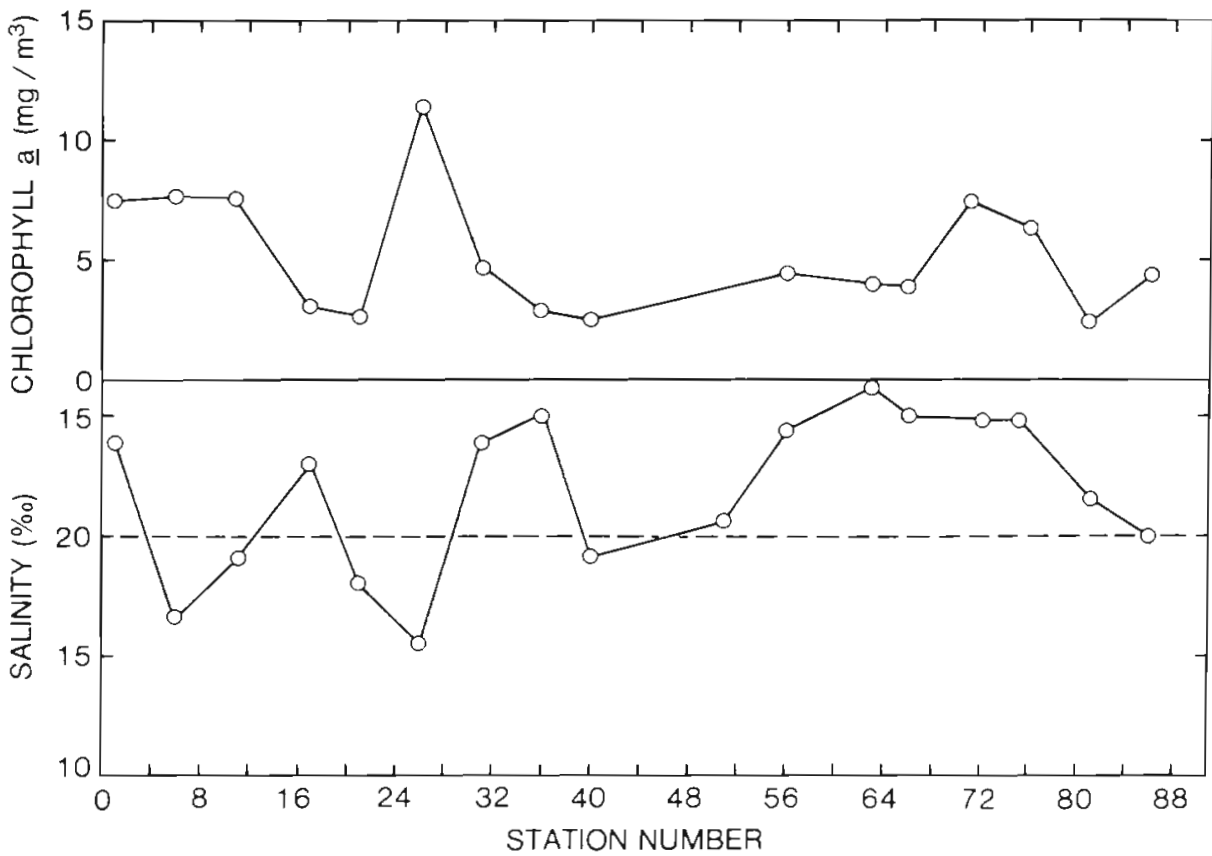

Fig. 5. Transect plots of chlorophyll a concentrations and salinities for sampling location of Fig. 2. Chlorophyll $a$ and salinity data provided by D. Mackas, Institute of Ocean Sciences 
Fig. 6. Transect plots of bacterialspecific productivities for sampling locations of Fig. 2. Replot of data of Fig. 4

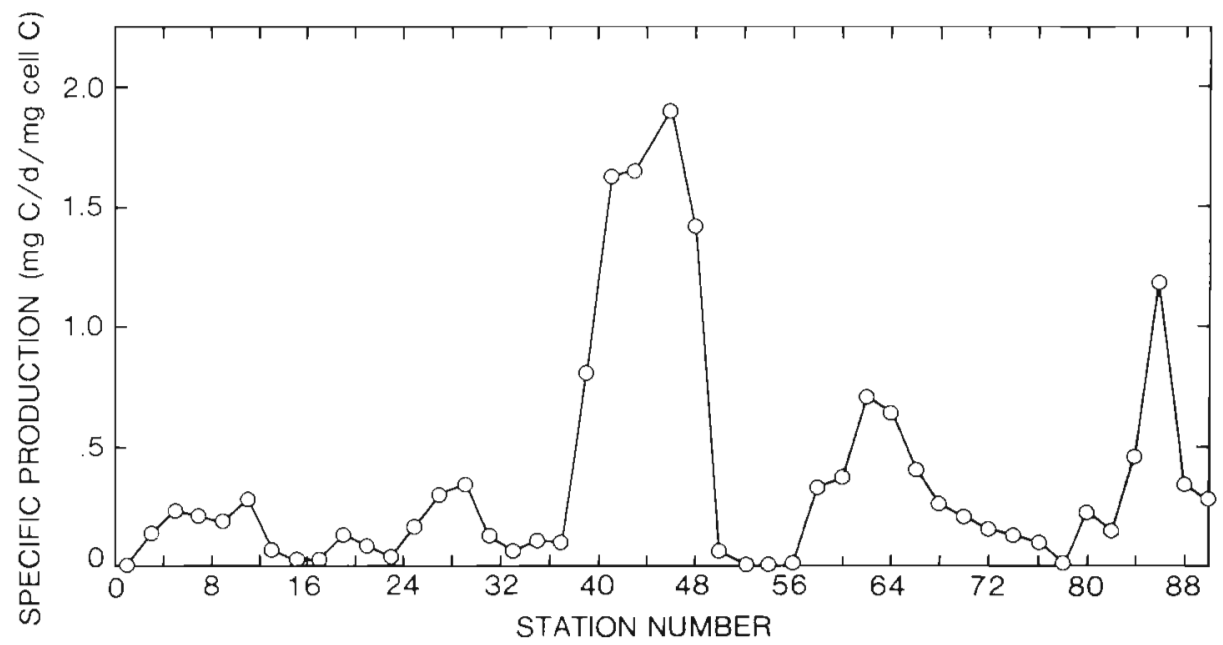

teria probably originate in the Fraser plume. Within this plume there appear to be 2 processes which stimulate bacterial activities and productivities. One occurs in the lower plume salinities of 0 to $\mathrm{ca} .18 \% \mathrm{~S}$ and appears to result from the mixing of river and Strait waters to form a more nutritious milieu (Bell and Albright, 1981; Valdes and Albright, 1981; Albright, 1983; see Fig. 3). The second is probably due to bacterial use of autochthonous organic carbon produced by the phytoplankton which occur (particularly in spring and fall) in the outer and higher salinity regions of the Fraser plume (Parsons et al., 1969). As these lower salinity surface waters from the Fraser plume circulate in a generally counterclockwise movement within the Strait they transport water masses with variable nutrient and bacterial compositions. This may account for most of the peaks in bacterial productivities noted along the transect lines (Figs. 2 and 4).

The enhancement of bacterial productivities in surface water between Stevens Passage (\#58) and Ajax Bank (\#68) of the Northern Domain (Figs. 2 and 4) is clearly not related to river outflow; nor does it appear to be a consequence of high phytoplankton biomasses (Fig. 4; see also Mackas et al., 1980 and Parsons et al., 1981). This does, however, appear to be a region of zooplankton accumulation (Mackas et al., 1980; Parsons, 1981). It is therefore possible that bacterial productivities at this location during this sampling time may have been more a consequence of zooplankton activities than was the case elsewhere in the Strait of Georgia. Some investigators (e.g. Eppley et al., 1981) have noted that zooplankton may increase the flux rate of dissolved organic matter from phyto- to bacterioplankton.

The peaks in bacterial biomasses, which tend to occur within the lower salinity water of this strait, averaged $8.6 \mathrm{mg} \mathrm{C} \mathrm{m}^{-3}\left(1.5 \times 10^{12}\right.$ cells $\left.\mathrm{m}^{-3}\right)$ while the troughs, found in the higher salinity surface water, had a mean value of $3.9 \mathrm{mg} \mathrm{C} \mathrm{m}{ }^{-3}\left(5.9 \times 10^{11}\right.$ cells $\left.\mathrm{m}^{-3}\right)$ (Fig. 4); a difference of approximately 2.2 fold.

The maxima and minima in bacterial productivities were generally coincident with bacterial biomasses (Fig. 4); mean values were 3.30 and $0.38 \mathrm{mg} \mathrm{C} \mathrm{m}^{-3} \mathrm{~d}^{-1}$ respectively, a difference of 8.7 fold. These results imply that bacterial production is more responsive to environmental conditions than are cell numbers and biomasses.

Wright (1978) has suggested the use of a specific activity index (e.g. glucose heterotrophic activity/cell) to assess the relative physiological condition of bacterial cells within the aquatic environment. However, this calculation is limited by several considerations, such as the choice of substrate(s) used by an investigator. A perhaps more useful calculation would be that of a specific production index (i.e. bacterial production/cell), since cell growth - i.e. biomass formation - is the net result of the cell's total activity. Fig. 6 shows the results of these specific production calculations, based upon the bacterial production and biomass values of Fig. 4. These data indicate a specific production of $1.59 \mathrm{mg} \mathrm{C} \mathrm{d}^{-1} \mathrm{mg}^{-1}$ cell $\mathrm{C}\left(1.12 \times 10^{-14} \mathrm{~g} \mathrm{C} \mathrm{d}^{-1}\right.$ cell ${ }^{-1}$ ) in one of the more nutritious waters (Station 46) and ca. $0.011 \mathrm{mg} \mathrm{C} \mathrm{d}^{-1} \mathrm{mg}^{-1}$ cell $\mathrm{C}\left(1.75 \times 10^{-17} \mathrm{~g} \mathrm{C}\right.$ $\mathrm{d}^{-1}$ cell $^{-1}$ ) in one of the least nutritious waters (Station 56). This is a 640 fold range in bacterial productivity per cell - much greater than the changes in cell numbers and productivities.

These data are indicative of the responses of these bacteria to environmental conditions. The cells at Stations 15 to 17,33 to 37,52 to 56 and 78 have lowered production rates (mean $=0.25 \mathrm{mg} \mathrm{C} \mathrm{m}^{-3} \mathrm{~d}^{-1}$ ) with biomasses which did not fall below ca. $2.6 \mathrm{mg} \mathrm{C} \mathrm{m}^{-3}$ $\left(4 \times 10^{11}\right.$ cells $\left.\mathrm{m}^{-3}\right)$. It would therefore appear that although the cells have become semi-dormant, forces removing them from the water column have also diminished. One of these forces may be a decrease in 
predatory pressure at these lower bacterial concentrations. Another may be a decrease in sedimentation rates of these cells from the water column.

Within more nutritious water (e.g. Stations 39-50) the cells respond to more favourable conditions with relatively large increases in specific productivities, whereas the bacterial biomasses appear to be limited to ca. $9.33 \mathrm{mg} \mathrm{C} \mathrm{m}^{-3}$. The most likely explanation for this is that grazing pressures increase at these higher cell biomasses, although cell sinking and spontaneous lysis cannot be ruled out. Microalgal product inhibition of these bacteria is also a possibility, although one would expect an inhibitory influence on both cell productivities and biomass levels which did not occur. If grazing is the dominant influence then much of the bacterial appear to be cropped when it reaches ca. $9 \mathrm{mg} \mathrm{C} \mathrm{m} \mathrm{m}^{-3}$.

Fuhrman and Azam $(1980,1982)$ have noted that in a coastal water of the Southern California Bight bacterial production appeared to be closely related to phytoplankton biomass. I have not found this correlation (e.g. Figs. 4 and 5), although phytoplankters undoubtedly do influence the bacterial biomasses and productivities of the Strait of Georgia surface waters. In these surface estuarine waters bacterial production appears also to be greatly influenced by riverine discharge. However, at this time the relative contribution of autochthonous and allochthonous organic matter to bacterial production cannot be directly assessed since these 2 organic pools cannot be adequately assayed.

Lower salinity waters (i.e. $\leq$ ca. $20 \%$ S) from lotic systems (with particular reference to the Fraser river) cover extensive areas of the Central Domain of the Strait of Georgia throughout the year but are particularly prominent during the freshet months of May to August of each year. Hence, on temporal and areal bases, the heterotrophic bacterial production may significantly enhance the total microbial productivity of the lower salinity surface waters. Parsons et al. (1969) noted that the spring bloom of Fraser plume associated phytoplankton generally occurs from late February to late April of each year with the freshet of this river occurring in May through August (Bell and Albright, 1981). Since organic carbon and bacterioplankton levels of the Fraser plume are related to river discharge volumes (Bell and Albright, 1981), the possibility exists that zooplankton (particularly microzooplankton) diets may be supplemented with greater levels of bacterioplankton and detritus during freshet. This may result in zooplankton production within plume-associated waters occurring at greater rates and over a longer time period as compared to other coastal waters away from riverine discharge and hence dependent mainly upon autochthonous primary production. These observations may, in part, explain the midsummer peaks in certain plume associated zooplankton species, noted by Parsons et al. (1981) and Mackas et al. (1980).

Acknowledgements. I thank officers and crew of MSSV 'John Strickland' and CSS 'Vector' for aid in sampling. The aid of Dr. D. Mackas, Institute of Ocean Science, Patricia Boy, Saanich, B.C. in sampling, as well as for the chl a and salinity analyses of Fig. 4 is appreciated. I thank Dan Stroh for help in all other sample analyses. This research was supported by an operating grant from the Natural Sciences and Engineering Research Council of Canada.

\section{LITERATURE CITED}

Albright, L. J. (1983). Heterotrophic biomasses, activities and productivities within the Fraser river plume. Can. J. Fish. aquat. Sci. 40 (Suppl. 1): 216-220

Azam, F., Holm-Hansen, O. (1973). Use of tritiated substrates in the study of heterotrophy in seawater Mar. Biol. 23: 191-196

Bell, C. R., Albright, L. J. (1981). Attached and tree-tloating bacteria in the Fraser river estuary, British Columbia, Canada. Mar. Ecol. Prog. Ser. 6: 317-327

Daley, R. J., Hobbie, J. E. (1975). Direct counts of aquatic bacteria by a modified epifluorescent technique. Limnol. Oceanogr. 20: 875-881

Eppley, R. W., Horrigan, S. G., Fuhrman, J. A., Brooks, E. R. Price, C. C., Sellner, K. (1981). Origins of dissolved organic matter in southern California coastal waters: experiments on the role of zooplankton. Mar. Ecol. Prog. Ser. 6: 149-159

Fuhrman, J. A., Azam, F. (1980). Bacterioplankton secondary production estimates for coastal waters of British Columbia, Antarctica and California. Appl environ. Microbiol. 39: 1085-1095

Fuhrman, J. A., Azam F., (1982). Thymidine incorporation as a measure of heterotrophic bacterioplankton production in marine surface waters: evaluation and field results. Mar. Biol. 66: 109-120

Harrison, P. J., Fulton, J. D., Taylor, F. J. R., Parsons, T R. (in press). A review of the biological oceanography of the Strait of Georgia: pelagic environment. Can. J. Fish. aquat. Sci.

Hobbie, J. E., Daley, R. J., Jasper, S. (1977). Use of the Nuclepore filters for counting bacteria by fluorescent microscopy. Appl environ. Microbiol. 33: 1225-1228

Lamanna, C., Mallete, M. F., Zimmerman, I. (1973). Basic bacteriology: its biological and chemical background (4th ed.). Williams and Wilkins, Baltimore

Lamanna, C. Mallete, M. F. (1965). Basic bacteriology. Williams and Wilkins, Baltimore

Luria, S. E. (1960). The bacterial protoplasm: composition and organization. In: Gunsales, I. C., Stanier, R. Y (eds.) The bacteria: structure, Vol. 1. Academic Press, New York, p. $1-34$

Mackas, D. L., Louttit, G. C., Austin, M. J. (1980). Spatial distribution of zooplankton and phytoplankton in British Columbia coastal waters. Can. J. Fish. aquat. Sci. 37: $1476-1487$

Overbeck, J., Daley, R. J. (1973). Some precautionary comments on the Romanenko technique for estimating heterotrophic bacterial production. Bull. Ecol. Res. Comm. nat. Sci. Res. Counc. (Swed.) 17: 342-344

Parsons, T. R., Stephens, K., Le Brasseur, R. J. (1969). Production studies in the Strait of Georgia. I. Primary production 
under the Fraser river plume, February to May 1967. J. exp. mar. Biol. Ecol. 3: 27-38

Parsons, T. R., Albright, L. J., Parslow, J. (1980). Is the Strait of Georgia becoming more eutrophic? Can. J. Fish. aquat. Sci. 37: 1043-1047

Parsons, T. R., Stronach, J., Borstad, G. A., Louttit, G., Perry, R J. (1981). Biological fronts in the Strait of Georgia, British Columbia, and their relation to recent measurements of primary productivity. Mar. Ecol. Prog. Ser. 6: 237-242

Romanenko, V. I., Overbeck, J., Sorokin, Y. I. (1972). Estimation of production of heterotrophic bacteria using ${ }^{14} \mathrm{C}$. In: Sorokin, Y. I., Kadota, H. (eds.) Microbial production and decomposition in fresh waters. Blackwell, Oxford, p. $82-85$
Seki, H., Stephens, K. V., Parsons, T. R. (1969). The contribution of allochthonous bacteria and organic materials from a small river into a semi-enclosed area. Arch. Hydrobiol. 66: $37-47$

Valdes, M., Albright, L. J. (1981). Survival and heterotrophic activities of Fraser river and Strait of Georgia bacterioplankton within the Fraser river plume. Mar. Biol. 64: 231-241

Waldichuk, M. (1957). Physical oceanography of the Strait of Georgia, British Columbia. J. Fish. Res. Bd Can. 14: 321-486

Wright, R. T. (1978). Measurement and significance of specific activity in the heterotrophic bacteria of natural waters. Appl. environ. Microbiol. 36: 297-305

This paper was submitted to the editor; it was accepted for printing on March 16, 1983 